\title{
Universal precautions: A methodology for trauma-informed justice
}

\author{
Daniel J. Jones*
}

This article is related directly to the $6^{\text {th }}$ International Law Enforcement $\mathcal{E}$ Public Health (LEPH) Virtual Conference in March 2021.

\begin{abstract}
The research clearly indicates that the vast majority of individuals involved in the justice system who display offending behaviour have experienced trauma, victimization, or Adverse Childhood Experiences (ACEs). Knowing this to be empirically factual raises the question, why is this not highlighted in the training of police officers, correctional officers, parole and probation officers, crown prosecutors, defence lawyers, and judges alike? An understanding of the Justice Client and their complex trauma could have important consequences on how all justice actors interact with people who experience the justice system. Knowing that these individuals were often victims long before they were offending could bring a more compassionate lens to the justice system. Having traumatic experiences is not the cause of offending, but it is often present in the offending population. The prevalence of trauma among the offending population, who themselves have of ten traumatized their victims, suggests a much-needed change in how police are trained to interact with Justice Clients. This paper applies the concept of Universal Precautions from first aid training in the development of practical policy to create a justice system based in compassion.
\end{abstract}

Key Words Trauma Informed, Police, Justice System, Victim Offender Overlap

\section{INTRODUCTION}

The concept of the victim-offender overlap-namely, that there is a significant number of individuals that populate the justice system as both victim and offender-is well researched and documented. It has been examined and analyzed using different sets of data (Jones et al., 2019; Bucerius, Jones, et al., 2021; Sampson \& Lauristen, 1990; Silver et al., 2011).

Understanding the idea that many individuals with offending behaviour have a history of adverse childhood experiences (ACEs) and trauma will allow opportunities to better serve this population, referred to hereafter as the Justice Client. Adverse childhood experiences include, but are not limited to, family dysfunction, neglect, witnessing or hearing domestic violence, exposure to family members who have a substance abuse disorder or have been incarcerated, and their own criminal victimization. Individuals who have ACEs are more prone to substance use, abuse, and addiction (Dube et al., 2003). These individuals are also more susceptible to disease (cancer, COPD, diabetes, etc.), engaging in high-risk sexual behaviour, psychiatric disorders, and incarceration (Felitti et al., 1998; Danese \& McEwen, 2012; Felitti \& Anda, 2010; Schilling et al., 2007).

How justice system actors, beginning with the police and ending with courts and/or correctional officers, interact with the Justice Client has an impact on whether individuals will report their own victimization throughout their life course (Myer \& Williamson, 2020). It also has an impact on the potential for the individual to re-offend (Baker \& Gau, 2018; Tyler, 2017; Tankebe, 2013). By changing how justice system actors are trained and introducing trauma-informed practice and compassionate treatment of the Justice Client, we may be able to change the outcomes for these individuals.

\section{DISCUSSION}

The concept of Universal Precautions is taught in first aid classes across the globe, requiring people to treat all blood and bodily waste as contaminated with a virus, such as Hepatitis C, HIV, or COVID-19. This allows the first aider to remain safe when

Correspondence to: Daniel Jones, 4016-37 Avenue, Edmonton, AB T6L 7B2, Canada. E-mail: Dan.jones@edmontonpolice.ca.

To cite: Jones, D. (2021). Universal precautions: A methodology for trauma-informed justice. Journal of Community Safety and Well-Being, 6/3), 156-159. https://doi.org/ $10.35502 /$ jeswb. 194

@ Author(s) 2021. Open Access. This work is distributed under the Creative Commons BY-NC-ND license. For commercial re-use, please contact sales@sgpublishing.ca. gg PUBLISHING Published by SG Publishing Inc. CSKA Official publication of the Community Safety Knowledge Alliance. 
administering the needed help to the individual and protects the injured individual from potential contamination from the first aider. The percentage of people who have Hepatitis C in Canada is $0.6 \%$, HIV is $0.0006 \%$, and COVID- 19 is $2.17 \%$. Using this same methodology for trauma in the justice system would protect the officers as well as the Justice Client. The parallel can be drawn that trauma is also a health issue, and therefore police should be looking at this through a public health lens (Bucerius, Oriola, \& Jones, 2021). If the vast majority of Justice Clients have experienced trauma then the criminality and behaviours may be symptomatic of the traumatic injury. If there is education and an understanding of the impact of trauma, then a compassionate lens-utilizing the tenets of procedural justice, allowing participation or "voice," neutrality, conveying trustworthy motives, and dignity-used with the Justice Client, would lead to less resistance, requiring less force on the part of the police (Mazerolle et al., 2013; Tyler, 2017; Tyler \& Huo, 2002). When we examine the percentage of individuals in the justice system who have victimization histories, the need for Universal Precautions for Trauma becomes clear. According to Bucerius, Jones, et al. (2021), 97\% of incarcerated women and 95\% of incarcerated men experienced violent or sexual victimization in their lives, often in childhood and before their own involvement in the system as an offender. A significant amount of criminal offending, substance use, and antisocial behaviour is symptomatic as a result of trauma. The concept of trauma is not new to the criminal justice system, but a true understanding of who the Justice Client is tends to be very limited. The fact that the vast majority of incarcerated people, both men and women, have experienced victimization and/or ACEs prior to their first detected offence (Jones, 2020; Jones, Bucerius \& Haggerty, 2019; Finkelhore et al., 2015) needs to be taken account in how we train frontline police and correctional staff and others in the justice system. Providing justice system actors knowledge of the impacts of trauma on human development will lead to better understanding, resulting in changes in how the system treats these individuals.

The vast majority of frontline police and corrections training in North America focuses on officer safety training and what would be considered "hard skills": security, law, policies, and procedures (Blumberg et al., 2019). What is absent from most frontline justice academy syllabi is providing an understanding of the social determinants of crime and who the Justice Client is. This training and education about trauma, ACEs, and the Justice Client is also absent from the vast majority of law schools, criminology and criminal justice programs (James, 2020; Jones, 2020; Dierkhising \& Branson, 2016). This is not to say that the Justice Client is a homogenous group; however, there are specific factors, such as victimization, trauma, and ACEs, that play a role in the development of people and their justice interactions (Edalati et al., 2017).

The justice system as a whole has failed to properly educate justice actors on the realities of trauma faced by the Justice Client. This may contribute to the "us versus them" mentality, keeping score on sentence length as success for prosecutions, arrest numbers for police, and breaches for parole and probation (Sawyer \& Wagner, 2020). Recent world events have had an impact on policing, bringing the justice system under the microscope, as the murder of George Floyd by police in Minneapolis, Minnesota, the shooting of Jacob Blake by police in Kenosha, Wisconsin, and the murder of Breonna Taylor by police in Louisville, Kentucky, have all led to discussions of defunding the police and implementing massive justice reforms (Akbar, 2020; Watson et al., 2020).

There has been a move towards blending police and public health to work towards the concept of community safety and well-being (Bucerius, Oriola, \& Jones, 2021; Williams \& Jones, 2020). However, this focuses primarily on what police are doing and is not as prescriptive on how police interact with the community. The move towards trauma-informed policing provides police with a better understanding of the impacts of trauma in the lives of the people with whom police interact (Jones, 2020). Such an understanding, together with a move towards changing how police interact with communities, specifically the marginalized, vulnerable, and often overpoliced communities, in order to approach this interaction with a public health lens, cannot be achieved until police leaders start to acknowledge that what has been done in the past is not successful.

Professor Lawrence Sherman of the University of Cambridge once said, "We teach the police about law, not crime, then expect them to manage crime." This applies to the justice system's understanding of the individual Justice Client with whom they interact. The majority of police training programs fail to provide context about the high likelihood that an individual dealing with the police as both an offender and a victim has been subject to trauma. An understanding of trauma and its impact on human dealings with justice actors may lead to a more compassionate style of police interactions with the public.

The discourse that has come from the recent movement to defund or abolish the police is countered in the literature, where marginalized communities are able to discuss what they want from the police. The communities most impacted by police ask that the police not be abolished but that police officers act differently when engaging their communities (Samuels-Wortley, 2021; Pattillo, 1998). This request from the community reinforces the necessity for procedural justice. I posit that an understanding of the Justice Client will strengthen the likelihood that procedural justice will be used (Tyler, 2017; Tankebe, 2013).

For police leadership to dismiss events such as the murder of George Floyd by using the argument of it being "a one-off" or the "few bad apples" is irresponsible with respect to the community that the police serve. Tens of thousands of people turned out to protest the police across the globe. However, as the protest numbers faded, so too did the attention police leadership paid to the movement. Waning numbers of protesters does not remove the duty of police leadership to institute meaningful and measurable change. Taking into account the voices of citizens, as well as research that discusses wanting police presence but wanting the police to interact differently, represents input from the community that must be addressed in order to rebuild police legitimacy within the communities that they serve. We need only look at Tom Tyler's research on police legitimacy to understand the impact. He states it best here: "every interaction that the police have with the public is an opportunity to build or undermine police legitimacy" (Sunshine \& Tyler, 2003). 
The need for trauma-informed justice and the use of the Universal Precautions for Trauma concept could not be more pressing than it is right now. As we move to evolve and re-envision our justice systems, the development and delivery of the following training needs to occur with all frontline members:

\section{Indigenous Historical Trauma}

Provides the requisite understanding of the history and impact of colonization and government assimilation policies on Indigenous peoples and how it relates to today in a justice context.

(1) Trauma 101

Provides an understanding of the different forms of trauma to the frontline workers so that they can be aware of them and their impacts.

- Adverse Childhood Experiences

Provides specific training on ACEs to ensure that individuals who are interacting with people daily understand that ACEs are an actual injury to the brain that results in developmental issues that can contribute to negative behaviours and criminal conduct.

- Victim-Offender Overlap

Provides an understanding to the police community of who the Justice Client is, including the experiences of many individuals caught up in the justice system, such as victimization, trauma, homelessness, substance use disorder, and other contemporary issues.

- Procedural Justice

Discusses the impact and necessity of following the tenets of procedural justice to build legitimacy.

- Police \& Correctional Legitimacy

Provides an explanation as to why the concept of legitimacy matters and how it is achieved. Police and corrections alike rely on the concept of legitimacy, both with the community at large and the clients that they serve.

Lived Experience Presentation and Q\&A

It is vital that individuals taking this training have an opportunity to hear from and interact with individuals who have experienced the justice system after being arrested and incarcerated. This provides a full understanding of what people experience in the system, allowing individuals working in the system to identify and understand gaps.

This training has been developed and delivered to specific units as well as to recruit constables at the Edmonton Police Service and is currently being evaluated to determine its effectiveness.

\section{CONCLUSION}

In light of the research and the current climate, as well as recent incidents related to policing and justice systems from across the globe, it is necessary to focus on "how" police engage with the community rather than "what" the police are doing. Instituting training that provides people working in the justice system with an understanding of the concept of Universal Precautions for Trauma should have members behaving more compassionately in communities to work towards building legitimacy and increasing community satisfaction with the police. The research is clear that, when the community sees the police as a legitimate power holder, there is less offending and less re-offending, making the community safer based on interactions alone (Paternoster et al., 1997; Sunshine \& Tyler, 2003; Murphy \& Cherney, 2012; Reisig et al., 2014).

The recommendations are that justice actors receive additional training that applies customer service to police legitimacy and operations. Evaluations of Procedural Justice Training have concluded that it has long-term impacts on the reduced use of force by trained officers and increased positive perceptions of police from the community (Dai, 2020). The author believes this training will have additional positive impacts; however, the efficacy of this training must be evaluated and adjusted on an ongoing basis.

\section{CONFLICT OF INTEREST DISCLOSURES}

The author has no conflicts of interest to declare.

\section{AUTHOR AFFILIATIONS}

*The University of Huddersfield/Edmonton Police Service, Edmonton, $\mathrm{AB}$, Canada

\section{REFERENCES}

Akbar, Amna. (2020). An abolitionist horizon for police (reform). California Law Review, 108(6). https://www.californialawreview.org/print/ abolitionist-horizon-police-reform/

Baker, T., \& Gau, J. M. (2018). Female offenders' perceptions of police procedural justice and their obligation to obey the law. Crime \& Delinquency, 64(6), 758-781

Blumberg, D. M., Schlosser, M. D., Papazoglou, K., Creighton, S., \& Kaye, C. C. (2019). New directions in police academy training: A call to action. International Journal of Environmental Research and Public Health, 16(24), 4941.

Bucerius, S. M., Jones, D. J., Kohl, A., \& Haggerty, K. D. (2021). Addressing the victim-offender overlap: Advancing evidence-based research to better service criminally involved people with victimization histories. Victims \& Offenders, 16(1), 148-163.

Bucerius, S. M., Oriola, T. B., \& Jones, D. J. (2021). Policing with a public health lens-Moving towards an understanding of crime as a public health issue. The Police Journal, 0032258X211009577. https://doi. org/10.1177/0032258X211009577

Dai, M. (2020). Training police for procedural justice: An evaluation of officer attitudes, citizen attitudes, and police-citizen interactions. The Police Journal, 0032258X20960791. https://doi.org/10.1177/ $0032258 \times 20960791$

Dierkhising, C. B., \& Branson, C. E. (2016). Looking forward: A research and policy agenda for creating trauma-informed juvenile justice systems. Journal of Juvenile Justice, 5(1), 14-30.

Danese, A., \& McEwen, B. S. (2012). Adverse childhood experiences, allostasis, allostatic load, and age-related disease. Physiology \& Behavior, 106(1), 29-39.

Dube, S. R., Felitti, V. J., Dong, M., Chapman, D. P., Giles, W. H., \& Anda, R. F. (2003). Childhood abuse, neglect, and household dysfunction and the risk of illicit drug use: The adverse childhood experiences study. Pediatrics, 1711 (3), 564-572.

Edalati, H., Nicholls, T. L., Crocker, A. G., Roy, L., Somers, J. M., \& Patterson, M. L. (2017). Adverse childhood experiences and the risk of criminal justice involvement and victimization among homeless adults with mental illness. Psychiatric services, 68(12), 1288-1295.

Felitti, V. J., \& Anda, R. F. (2010). The relationship of adverse childhood experiences to adult medical disease, psychiatric disorders, and 
sexual behavior: Implications for healthcare. The impact of early life trauma on health and disease: The hidden epidemic, 77-87.

Felitti, V. J., Anda, R. F., Nordenberg, D., Williamson, D. F., Spitz, A. M., Edwards, V., \& Marks, J. S. (1998). Relationship of childhood abuse and household dysfunction to many of the leading causes of death in adults: The Adverse Childhood Experiences (ACE) Study. American Journal of Preventive Medicine, 14(4), 245-258.

Finkelhor, D., Turner, H. A., Shattuck, A., \& Hamby, S. L. (2015). Prevalence of childhood exposure to violence, crime, and abuse: Results from the national survey of children's exposure to violence. JAMA Pediatrics, 169(8), 746-754.

James, C. (2020). Towards trauma-informed legal practice: A review. Psychiatry, Psychology and Law, 27(2), 275-299.

Jones, D. J. (2020). Pandemic policing: Highlighting the need for traumainformed services during and beyond the COVID-19 crisis. Journal of Community Safety and Well-Being, 5(2), 69-72.

Jones, D. J., Bucerius, S. M., \& Haggerty, K. D. (2019). Voices of remanded women in Western Canada: A qualitative analysis. Journal of Community Safety and Well-Being, 4(3), 44-53.

Mazerolle, L., Bennett, S., Davis, J., Sargeant, E., \& Manning, M. (2013). Procedural justice and police legitimacy: A systematic review of the research evidence. Journal of Experimental Criminology, 9(3), 245-274

Meyer, S., \& Williamson, H. (2020). General and specific perceptions of procedural justice: Factors associated with perceptions of police and court responses to domestic and family violence. Australian \& New Zealand Journal of Criminology, 53(3), 333-351.

Murphy, K., \& Cherney, A. (2012). Understanding cooperation with police in a diverse society. The British Journal of Criminology, 52(1), 181-201.

Paternoster, R., Bachman, R., Brame, R., \& Sherman, L. W. (1997). Do fair procedures matter-the effect of procedural justice on spouse assault. Law \& Society Review, 37, 163.

Pattillo, M. E. (1998). Sweet mothers and gangbangers: Managing crime in a black middle-class neighborhood. Social Forces, 76(3), 747-774.
Reisig, M. D., Tankebe, J., \& Mesko, G. (2014). Compliance with the law in Slovenia: The role of procedural justice and police legitimacy. European Journal on Criminal Policy and Research, 20(2), 259-276.

Sampson, R. J., \& Lauritsen, J. L. (1990). Deviant lifestyles, proximity to crime, and the offender-victim link in personal violence. Journal of Research in Crime and Delinquency, 27(2), 110-139.

Samuels-Wortley, K. (2021). To serve and protect whom? Using composite counter-storytelling to explore Black and Indigenous youth experiences and perceptions of the police in Canada. Crime \& Delinquency, 0011128721989077 . https://doi.org/10. $1177 / 0011128721989077$

Sawyer, W., \& Wagner, P. (2020, March 24). Mass incarceration: The whole pie 2020. Prison Policy Initiative, Press release.

Schilling, E. A., Aseltine, R. H., \& Gore, S. (2007). Adverse childhood experiences and mental health in young adults: A longitudinal survey. BMC Public Health, 7(1), 1-10.

Silver, E., Piquero, A. R., Jennings, W. G., Piquero, N. L., \& Leiber, M. (2011). Assessing the violent offending and violent victimization overlap among discharged psychiatric patients. Law and Human Behavior, 35(1), 49-59.

Sunshine, J., \& Tyler, T. R. (2003). The role of procedural justice and legitimacy in shaping public support for policing. Law \& Society Review, 37(3), 513-548.

Tankebe, J. (2013). Viewing things differently: The dimensions of public perceptions of police legitimacy. Criminology, 5111), 103-135.

Tyler, T. (2017). Procedural justice and policing: A rush to judgment? Annual Review of Law and Social Science, 13, 29-53.

Tyler, T. R., \& Huo, Y. (2002). Trust in the law: Encouraging public cooperation with the police and courts. Russell Sage Foundation.

Watson, M. F., Turner, W. L., \& Hines, P. M. (2020). Black Lives Matter: We are in the same storm but we are not in the same boat. Family Process, 59(4), 1362-1373.

Williams, U., \& Jones, D. J. (2020). Delineating policing towards a social and health profession. Journal of Community Safety and Well-Being, 5(4), 156-163. 